\title{
Ichthyosaurs from the Jurassic of Skye, Scotland
}

\author{
Stephen L. Brusatte ${ }^{1,2 *}$, Mark T. Young, ${ }^{1,3}$, Thomas J. Challands ${ }^{1}$, Neil D. L. Clark ${ }^{4, \#,}$ \\ Valentin Fischer ${ }^{5, \#}$, Nicholas C. Fraser ${ }^{1,2, \#, ~ J e f f ~ J . ~ L i s t o n ", ~ 6, ~ 7, ~ \#, ~ C o l i n ~ C . ~ J . ~ M a c F a d y e n ~}{ }^{8, \#, ~}$ \\ Dugald A. Ross, , , Stig Walsh", 2, \# \& Mark Wilkinson", \# \\ ${ }^{1}$ School of GeoSciences, University of Edinburgh, Grant Institute, the King's Buildings, James Hutton Road, Edinburgh \\ EH9 3FE, UK \\ ${ }^{2}$ National Museums Scotland, Chambers Street, Edinburgh EH1 1JF, UK \\ ${ }^{3}$ School of Ocean and Earth Science, National Oceanography Centre, University of Southampton, Southampton SO14 \\ $3 \mathrm{ZH}, \mathrm{UK}$ \\ ${ }^{4}$ The Hunterian Museum, University of Glasgow, University Avenue, Glasgow G12 8QQ, UK \\ ${ }^{5}$ Geology Department, University of Liege, B18 Allée du Six Août, 4000 Liège, Belgium \\ ${ }^{6}$ Yunnan Key Laboratory for Palaeobiology, Yunnan University, Kunming, People's Republic of China \\ ${ }^{7}$ Institute of Biodiversity, Animal Health and Comparative Medicine, College of Medical, Veterinary and Life Sciences, \\ University of Glasgow, Glasgow G12 8QQ, UK \\ ${ }^{8}$ Scottish Natural Heritage, Silvan House, 231 Corstorphine Road, Edinburgh EH12 7AT, UK \\ ${ }^{9}$ Staffin Museum, 6 Ellishadder, Staffin, Isle of Skye IV51 9JE, UK \\ \# Authors listed alphabetically \\ * Correspondence: Stephen.Brusatte@ed.ac.uk
}

\begin{abstract}
Fossils of Mesozoic vertebrates are rare in Scotland, particularly specimens of marine reptiles such as plesiosaurs and ichthyosaurs. We describe a suite of ichthyosaur fossils from the Early to Middle Jurassic of Skye, which to our knowledge are the first ichthyosaurs from Scotland to be described and figured in detail. These fossils span approximately 30 million years, from the Sinemurian to the Bathonian, and indicate that ichthyosaurs were a major component of Scottish marine faunas during this time. The specimens include isolated teeth that could represent the most northerly known occurrences of the widespread Sinemurian species Ichthyosaurus communis, a characteristic component of the famous Lyme Regis faunas of England, suggesting that such faunas were also present in Scotland during the Early Jurassic. An associated humerus and vertebrae from Toarcian-Bajocian-aged deposits are named as a new genus and species of basal neoichthyosaurian, Dearcmhara shawcrossi. The taxonomic affinities of this taxon, which comes from a critical but poorly sampled interval in the fossil record, suggest that non-ophthalmosaurid neoichthyosaurians dominated European assemblages around the Early-Middle Jurassic boundary, and were later replaced by ophthalmosaurids, whose radiation likely took place outside Europe. Many of these specimens were collected by amateurs and donated to museum collections, a co-operative relationship essential to the preservation of Scotland's fossil heritage.
\end{abstract}

Received 3 July 2014; accepted 3 November 2014

\section{Introduction}

Fossils of dinosaurs, marine reptiles, and other Mesozoic vertebrates are rare in Scotland, despite 150+ years of collecting dating back to the legendary Hugh Miller (Miller 1858). The importance of the Scottish record, however, is far out of proportion to its quality. Scotland boasts one of the world's premier Middle Jurassic small vertebrate faunas (Evans \& Milner 1994; Evans et al. 2006), which includes spectacularly well-preserved specimens of one of the oldest turtles (Anquetin et al. 2009) and some of the closest relatives of mammals (Waldman \& Savage 1972). Tantalizing bones and footprints of dinosaurs have been found in several Early-Middle Jurassic units, making Scotland one of the rare places in the world to yield dinosaurs from this under-sampled time interval (Andrews \& Hudson 1984; Benton et al. 1995; Clark et al. 1995, 2004, 2005; Clark \& Rodríguez 1998; Clark 2001; Liston 2004; Marshall 2005; Barrett 2006). Most of these new discoveries have come to light over the past 25 years and, during this time, Scotland has emerged as a growing, but still underappreciated, centre of Mesozoic vertebrate palaeontology research.

Nearly all Scottish Mesozoic vertebrate fossils come from the Jurassic of the Hebrides, particularly the Isle of Skye (Fig. 1) and the nearby smaller islands of Eigg and Raasay (Benton \& Spencer 1995; Evans et al. 2006). Dinosaurs, stem mammals, turtles, squamates and lissamphibians from Skye have been the focus of most recent work on the Hebridean vertebrates, and have been well described and figured in the literature (e.g. Waldman \& Savage 1972; Waldman \& Evans 1994; Benton et al. 1995; Clark et al. 1995; Anquetin et al. 2009).

Surpisingly perhaps, marine reptiles have received comparatively little attention. Research on the Hebridean vertebrates began with Miller's (1858) pioneering description of a plesiosaur bonebed on Eigg. This was followed by numerous mentions of Hebridean marine reptile (plesiosaur and ichthyosaur) specimens in the literature (e.g. Lee \& Buckman 1920; Arkell 1933; Hudson 1966; Hudson \& Morton 1969; Martill 1985; Benton et al. 1995; Page \& 


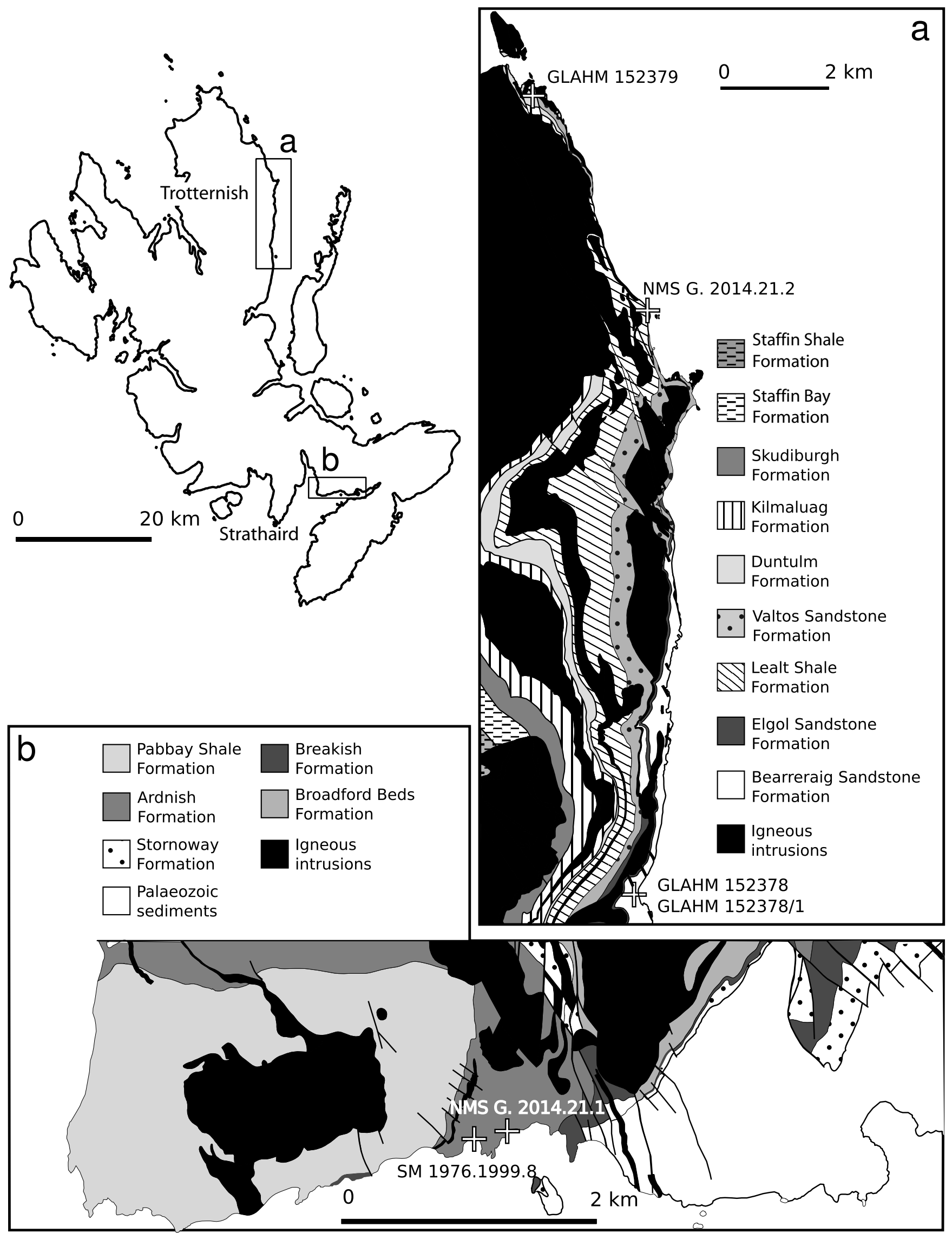

Fig. 1. Map of Skye, Scotland, showing the geographical and geological context for the ichthyosaur specimens described in this paper. Maps adapted from BGS 1:50 000 [Shapefile geospatial data], Scale 1:50 000, Tile: SC071W, SC080E, SC090, Version 2014, British Geological Survey, UK. Using: EDINA Geology Digimap Service, http://edina.ac.uk/digimap, downloaded May 2014. 
Wimbledon 2008), but only one of these - an associated set of plesiosaur vertebrae, ribs and gastralia - has been described and figured in any detail (Clark et al. 1993). Therefore, little is currently known about the age, provenance, anatomy and systematics of Early to Middle Jurassic marine reptiles from Scotland, despite the apparently large number of specimens. This is especially problematic because part of the time period spanned by the Hebridean fossiliferous units, particularly parts of the Middle Jurassic, are relatively poorly sampled intervals in marine reptile evolution. As a result, the Scottish specimens may offer important insights into marine reptile evolution and biogeography during this time.

We here describe a suite of ichthyosaur fossils from the Early-Middle Jurassic of Skye. To our knowledge, these are the first ichthyosaur fossils from the Hebrides (and Scotland more broadly) to be described and figured in detail. These specimens include portions of skulls, teeth, vertebrae and a partial humerus, which were collected by different teams of scientists and fossil enthusiasts over the past 50+ years and subsequently accessioned into the collections of National Museums Scotland (Edinburgh), the Hunterian Museum (Glasgow) and the Staffin Museum (Isle of Skye). These specimens include material that could pertain to the widespread species Ichthyosaurus communis, well known from the famous Lyme Regis fauna, in the Early Jurassic and material that represents a new genus and species of basal neoichthyosaurian with a highly distinctive humerus from the Early-Middle Jurassic.

\section{Geological context}

As well as featuring the most complete succession of Mesozoic rocks in Scotland, preserving sediments from the Upper Triassic to the Upper Jurassic (Kimmeridgian), the Inner Hebrides record one of the least interrupted sequences of Middle Jurassic rocks in the world (Figs 1,2). Within the Inner Hebrides, rocks of this age crop out from as far north as the Shiant Isles in The Minch, east of the Isle of Harris, to the southern coast of Mull (Morton \& Hudson 1995). Jurassic sediments in the Inner Hebrides rest conformably on top of coarse-grained Triassic fluvial sediments which, in turn, unconformably overlie Precambrian-Cambrian basement and sediments. These Mesozoic sediments were deposited in two individual fault-bounded basins, the Sea of the Hebrides Basin (Trotternish Peninsula) and the Inner Hebrides Basin (Strathaird Peninsula), and reflect changing relative sea level influenced by tilting in the tectonically bound basins (Morton 1987; Mellere \& Steel 1996). The two depocentres were separated by a positive topographic feature, the Skye High (Morton 1965; Hesselbo et al. 1998), but there is debate about the degree of separation the two basins experienced (Harris 1992; Mellere \& Steel 1996). However, there are clearly time-equivalent deposits of different facies on both the Strathaird and Trotternish peninsulas, with individual lithological units exhibiting diachroneity (Morton \& Hudson 1995; Hesselbo et al. 1998).

Dating of the Hebridean Jurassic units is generally robust and is based on ammonites found throughout the sequence (Morton 1971, 1972), although some units lack or have a scarcity of ammonites (e.g. lower Broadford Beds Formation,
Valtos Sandstone Formation, Duntulm Formation). Where age-diagnostic ammonites have not been found or where ammonites are absent altogether, the age of units can often be determined with confidence from bivalve, gastropod and conchostracan associations (Torrens 1980; Chen \& Hudson 1991) and palynomorphs (Riding et al. 1991).

The Jurassic sediments of Skye owe their preservation, in part, to the erosion-resistant overlying Cenozoic basaltic volcanics that are pervasive throughout the Inner Hebrides. Basaltic and microgabbroic sills and dykes, associated with plutonic centres formed during a phase of Paleocene volcanism, penetrate Mesozoic sediments and have a NW-SE regional strike. Contact metamorphism from this dense swarm of intrusive rocks resulted in only minor thermal alteration of the adjacent Mesozoic sediments by no more than a few metres in the majority of cases, although some localities (e.g. the Kilmaluag Formation, Strathaird Peninsula) exhibit more pervasive contact metamorphism and are consequentially more indurated (Thrasher 1992).

The specimens described in this paper were recovered from units spanning the Lower to Middle Jurassic (Figs 1, 2). Specimens were recovered either directly from or closely associated with the Ardnish Formation, the Bearreraig Sandstone Formation, the Valtos Sandstone Formation and the Duntulm Formation. In the following descriptions of the individual formations we use the stratigraphic nomenclature as currently employed by the British Geological Survey. The ammonite biostratigraphy herein employs the 'standard' zones used in the most recent Geological Conservation Review series for British Jurassic stratigraphy (Wright \& Cox 2001; Cox \& Sumbler 2002; Simms et al. 2004). In this scheme, where the actual ammonite zone cannot be identified, the 'zones' are treated as chronostratigraphic subdivisions. Each such subdivision can be recognized by ammonite faunas but is not defined by them. Ammonite zones from both the Boreal and sub-Boreal provinces are included in this scheme and, subsequently, the scheme cannot be solely attributed to either of these provincial zonal schemes. This is particularly appropriate for the Upper Jurassic of Skye where Oxfordian and Kimmeridgian ammonites represent both provinces (Matyja et al. 2005).

\section{Ardnish Formation, Hallaig Sandstone Member, Loch Eishort}

The Ardnish Formation (=Upper Broadford Beds of Hallam 1959; Lower Pabbay Shale of Hesselbo et al. 1998) at the Loch Eishort exposure is early Sinemurian in age (Caesinites turneri ammonite Zone, Hesselbo et al. 1998). Here the Ardnish Formation predominantly comprises micaceous shales and siltstones with clean, medium- to fine-grained sandstones exhibiting bipolar tabular and trough cross-beds (e.g. the Hallaig Sandstone Member of Hesselbo et al. 1998). These cross-bedded units, which contain abundant marine fossils at the bases of coarsening-up cycles, are interpreted as representing deposition in a shallow-marine/ estuarine environment with a tidal influence (Hesselbo \& Coe 2000). Precise dating is not possible but the $C$. turneri Zone has been assigned on the possible presence of Caenisites (Hallam 1959) and ?Microdoceras (Oates 1976). 


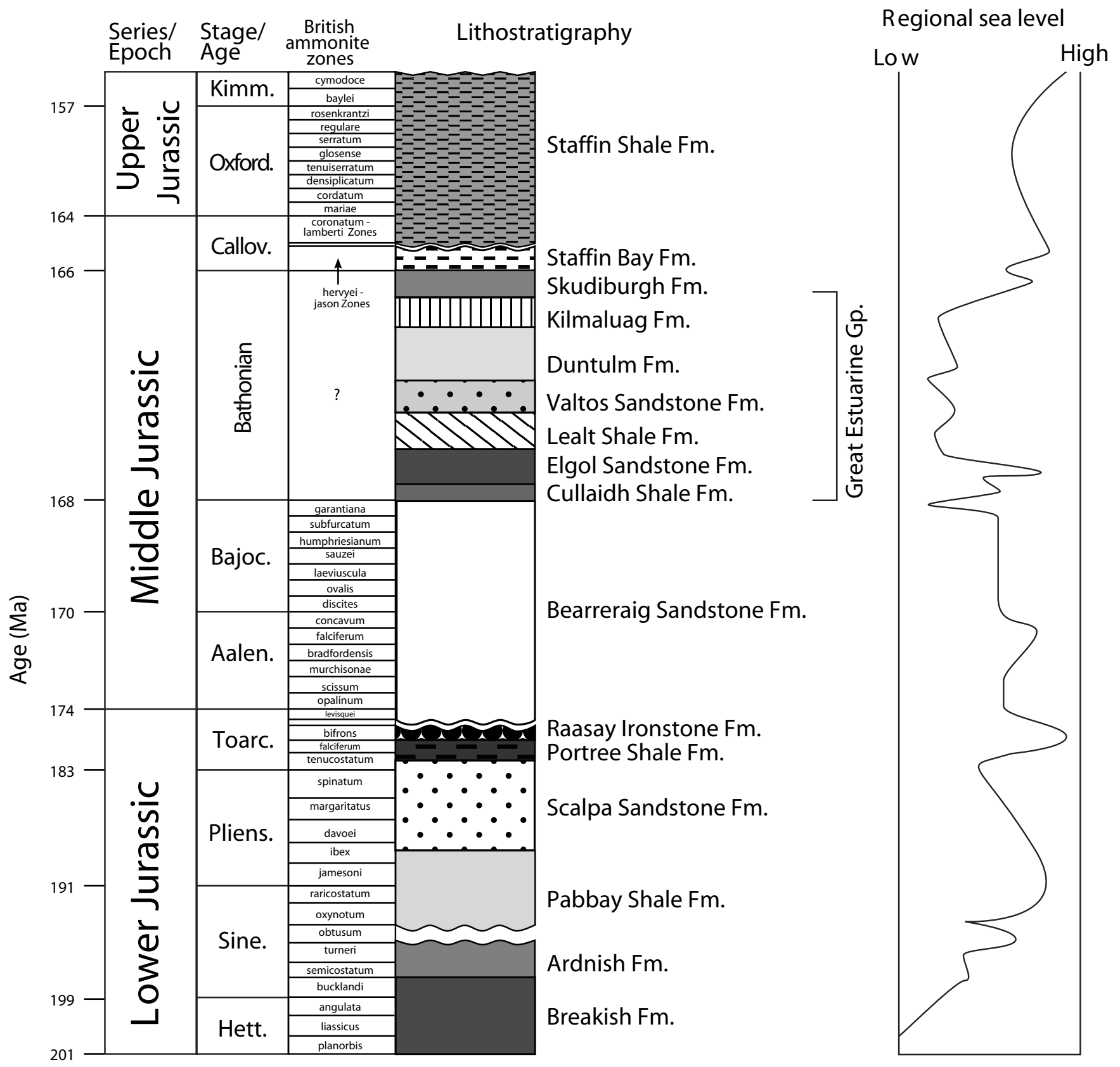

Fig. 2. Geological column and interpreted regional sea-level curve of Inner Hebrides Mesozoic stratigraphy. Ammonite biostratigraphy from Hesselbo et al. (1998) and Hesselbo \& Coe (2000). Regional sea-level curve adapted from Hesselbo \& Coe (2000) and Hesselbo (2008).

\section{Bearreraig Sandstone Formation}

The Bearreraig Sandstone Formation at Bearreraig Bay records three coarsening-up parasequences (Morton 1965). The first of these is represented by fine-grained, burrowed muddy sandstones of the Dun Caan Shale Member (late Toarcian, Pleydellia aalensis Subzone, to early-mid-Aalenian, Ludwigia murchisonae Zone), which are overlain by fossiliferous calcareous sandstones of the late Aalenian (Graphoceras concavum Zone) Ollach Sandstone Member, which contains conspicuous large calcareous concretions (Wilkinson 1991; Morton \& Hudson 1995; Mellere \& Steel 1996). Abrupt deepening resulted in deposition of micaceous mudstones, siltstones and very fine-grained sandstones of the Udairn Shale Member (late Aalenian, G. concavum Zone to early Bajocian, Sonninia ovalis Zone), which grades upwards into the fine-grained Holm Sandstone Member (midLower Bajocian, Withchellia laeviscula Zone). Largescale cross-stratification in the Holm Sandstone Member was interpreted by Mellere \& Steel (1996) as being formed by large, shallow-marine sand waves migrating in a tidal channel. The overlying clay and silt-rich layers of the Rigg Sandstone Member (upper Emileia saueziStephanoceras humphriesianum Zones of the late Lower Bajocian) herald the final deepening event in the Bearreraig Sandstone Formation before deposition of the overlying Bathonian-age Cullaidh Shale Formation.

\section{Valtos Sandstone Formation}

The Valtos Sandstone Formation of the Great Estuarine Group comprises alternating sequences of shelly limestones (containing an abundance of the bivalve Neomiodon), 
mudstones and sandstones representing repetitive cycles of progradation and retrogradation of delta systems into a marine-influenced lagoon (Harris 1992; Wilkinson 1993). Three major units were recognized by Harris (1992). The first is a lower unit exhibiting cycles passing from mudstones to shell-rich horizons, which coarsen up into fine-grained sandstones and coarser-grained cross-bedded sandstones with ripples. The coarser-grained sandstone units are interpreted as distributary channel sands and thin delta-top beds. The second and third units are a middle shale-limestonedominated unit and an upper sandstone-dominated unit (well exposed at Rubha Garbhaig). The age of the Valtos Sandstone Formation is late Bajocian-Bathonian, based on palynological and macrofaunal fossils (Riding et al. 1991). The presence of Lycopodiacidites baculatus indicates that the Valtos Sandstone Formation is no younger than early Bathonian, as this taxon does not occur in post-Bathonian strata in Europe (Riding et al. 1991). The formation yields a predominantly terrestrial freshwater microflora, as well as dinosaur bones and footprints (e.g. Clark \& Barco Rodríguez 1998).

\section{Duntulm Formation}

The Duntulm Formation comprises heterolithic mudstones with conspicuous oyster beds dominated by Praeexogyra hebredica towards the base of the formation (Harris 1992). Limestone bands, stromatolitic algal limestones and burrowed calcareous sandstones yielding dinosaur footprints (Clark et al. 2004) occur higher in the section. At the type locality at Cairidh Ghlumaig, at Duntulm in NW Trotternish, a marine influence is indicated by the appearance of the bivalves Pacunopsis, Cuspidaria, Modiolus and subsequently Praeexogyra. Here shark fin spines and fragmentary fish remains are present but other nektonic marine organisms such as ammonites are not found (Morton \& Hudson 1995). The dinoflagellate flora suggests a near-shore marine environment (Riding et al. 1991), whereas the sedimentology of this unit was interpreted by Hudson (1970) and Andrews (1986) as being indicative of a marginal lagoonal mudflat setting with the algal limestone bands representing a littoral fringe with a microtidal influence in a marine-brackish lagoon (Hudson \& Andrews 1987). At Lon Ostatoin, near Duntulm, a low salinity bivalve fauna of Neomiodon and Unio, together with the green alga Botryococcus, demonstrates a freshwater influence during deposition of parts of the Duntulm Formation (Riding et al. 1991; Morton \& Hudson 1995). The palynomorph assemblage strongly supports a Bathonian age for the Duntulm Formation, and the presence of the bivalve Praeexogyra implies a mid-late Bathonian age, although it is to be noted that the distribution of Praeexogyra is known to be strongly controlled by facies (Hudson in Torrens 1980; Riding et al. 1991).

\section{Institutional abbreviations}

GLAHM, The Hunterian Museum, University of Glasgow, Glasgow, Scotland, UK; NHMUK, The Natural History Museum, London, England, UK; NMS, National Museums Scotland, Edinburgh, Scotland, UK; SM, Staffin Museum, Isle of Skye, Scotland, UK.

\section{Systematic palaeontology}

REPTILIA Laurenti 1768

ICHTHYOSAURIA de Blainville 1835

ICHTHYOSAURUS De la Beche \& Conybeare 1821 cf. Ichthyosaurus communis Conybeare 1822

Figures 3, 4

Neotype. NHMUK PV R1162: skull and skeleton.

Distribution of I. communis. Lower Jurassic (basal Hettangian-lower Sinemurian) of Lyme Regis, Dorset, and Street, Somerset, England (McGowan \& Motani 2003). Lower Sinemurian of Frick, Canton Aargau, Switzerland (Maisch et al. 2008). Upper Sinemurian of Lorraine, Belgium (Godefroit 1996). Bennett et al. (2012) referred an incomplete skeleton (NHMUK PV R15907) from the Pliensbachian of Stonebarrow, Dorset, England, to Ichthyosaurus communis. However, based on their figures it appears to lack several of the apomorphies of this species (listed below). Pending closer study of the specimen, we currently do not consider it to be strong evidence that $I$. communis continued into the Pliensbachian. Possibly also the early Sinemurian of the Isle of Skye, Scotland.

Diagnosis of I. communis. Preflexural vertebrae $>74<80$; presacral vertebrae $>41$. Snout moderately long, snout ratio $>0.57-0.69$. Orbits are not exceptionally large, the orbit ratio is typically $0.20-0.28$, but usually $<0.25$. Fewer than 20 teeth per maxilla. Tooth crown apices are blunt, whereas the crowns are robust and curved. Tooth crown-root junction is not abrupt (i.e. does not have a narrow crown and an inflated root) as in Ichthyosaurus intermedius. Tooth roots are somewhat rectangular in cross-section. Very large lacrimal anterior process, which sutures with the premaxilla along its dorsal and anterior margins and the maxilla along its ventral margin. Jugal with a rounded external surface (when seen in cross-section). Quadratojugal is moderately short dorsoventrally, being distinctly less than two-thirds of the orbital height. Quadrate ascending plate is robust, not a thin lamina as in Ichthyosaurus intermedius. (Modified from McGowan \& Motani 2003; Maisch et al. 2008; Bennett et al. 2012.)

Skye material. SM 1976.1999.8: block containing the impression of the ventral surface of an ichthyosaur lower jaw and 21 separated teeth, some of which preserve portions of the enamel (Figs 3, 4). NMS G. 2014.21.1: single isolated tooth root (Fig. 4).

Provenance. SM 1976.1999.8 was found loose on the shore at Boreraig (Suisnish, south Skye) by one of the authors (C.C.J.M.) in 1997 (MacFadyen 1997) (Fig. 1). It was later collected by another of the authors (D.A.R.) and Martin Wildgoose in 1999. Based on lithological comparison to the rocks near where it was recovered, the specimen derives from the Hallaig Sandstone Member of the Ardnish Formation (C. turneri ammonite zone, late lower Sinemurian). NMS G. 2014.21.1 was found during a 2013 field trip by one of the authors (T.J.C.) in the Hallaig Sandstone Member of the Ardnish Formation (C. turneri ammonite zone, late lower Sinemurian) (Fig. 1). 


\section{S. L. Brusatte et al.}
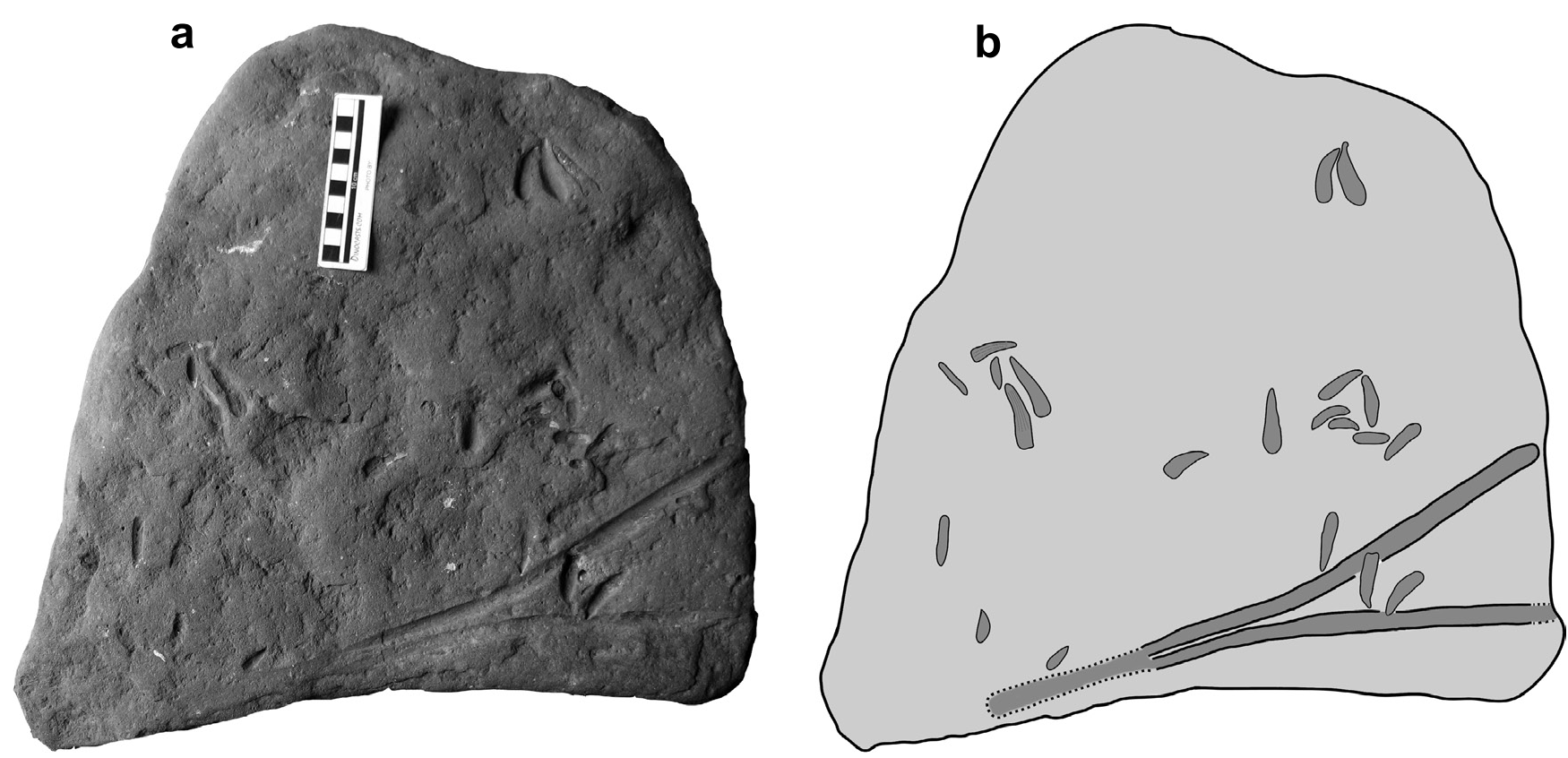

Fig. 3. (a) Photograph and (b) line drawing of a block preserving the imprint of a cf. Ichthyosaurus communis lower jaw and several teeth (SM 1976.1999.8) from the Early Jurassic (early Sinemurian) Ardnish Formation of Skye, Scotland. Scale bar $10 \mathrm{~cm}$.

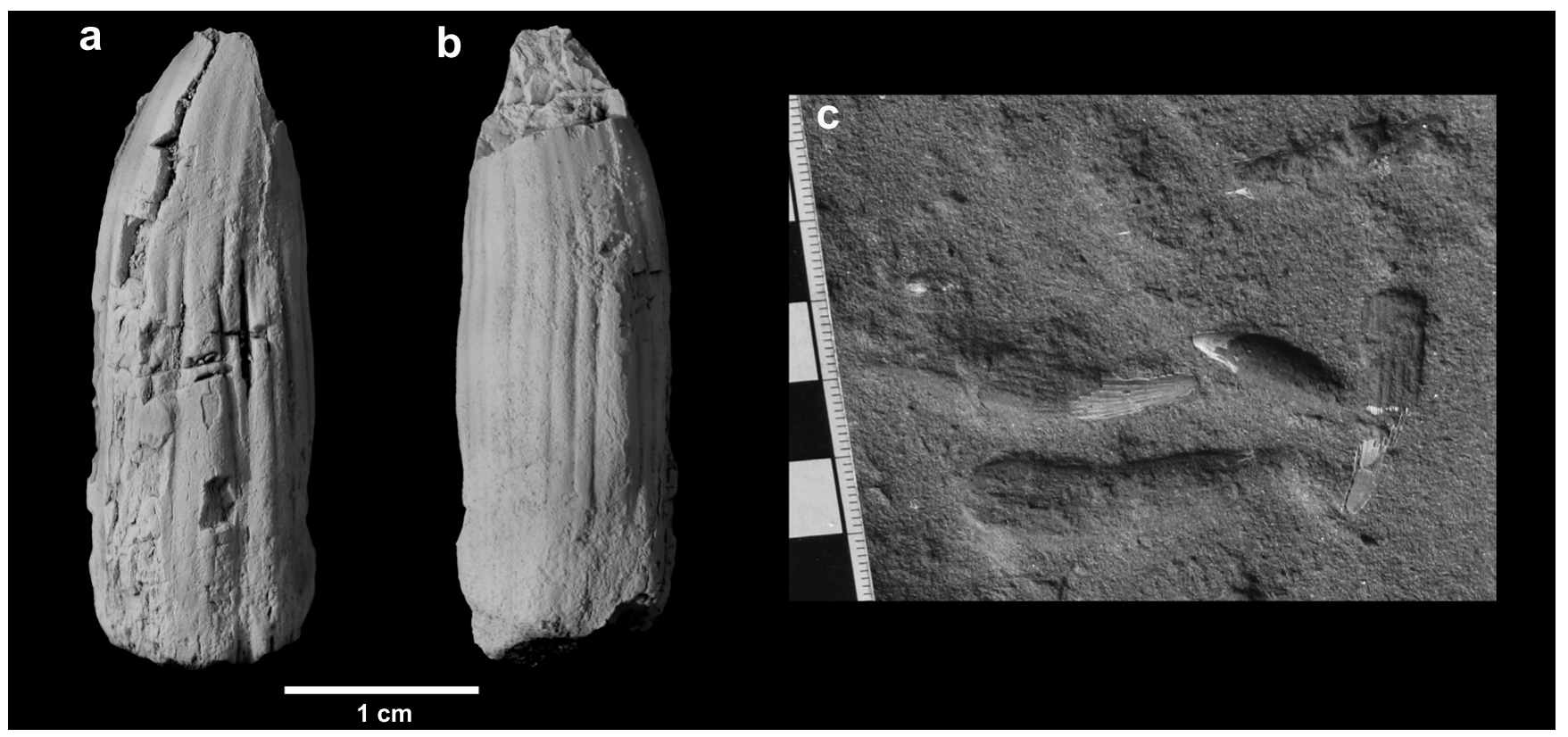

Fig. 4. Cf. Ichthyosaurus communis teeth from the Early Jurassic (early Sinemurian) Ardnish Formation of Skye, Scotland. (a-b) Labial and lingual photographs of an isolated tooth preserved in three dimensions (NMS G. 2014.21.1). (c) Close-up of the best preserved teeth on the ichthyosaur block illustrated in Figure 3 (SM 1976.1999.8).

Description. The isolated tooth NMS G. 2014.21.1 preserves only an incomplete root (Fig. 4). It would have been from a fairly large tooth, as the root is $10 \mathrm{~mm}$ wide mesiodistally and $8 \mathrm{~mm}$ wide labiolingually at its preserved base. On all surfaces there are numerous, deep, continuous apicobasally aligned grooves. There is no evidence that the root was bulbous compared to the crown (i.e. that it widened mesiodistally-labiolingually basal to the crown-root junction) as the root has almost parallel margins until the apical region, where it narrows slightly and curves in a distal-lingual manner. The root is slightly rectangular in cross-section.

The specimen SM 1976.1999.8 preserves the ventral outline of a lower jaw, the outline of numerous disassociated teeth, and some incomplete teeth on a slab (Fig. 3). The lower jaw impression shows both rami converging towards the symphyseal region, and what appears to be the middleposterior portion of the symphyseal region. The two rami were apparently disassociated along the symphyseal suture, based upon the impression they left. The tooth impressions show numerous fairly robust teeth which would have curved lingually. From the impressions and portions of the enamel of the preserved tooth crowns, the apices were all blunt and rounded. Where the enamel can be discerned, there are numerous, continuous apicobasally aligned ridges. These are present on all exposed enamel surfaces, including on the root (Fig. 4c). 
In the Sinemurian of Europe, four genera of ichthyosaurs are recognized: Excalibosaurus, Ichthyosaurus, Leptonectes and Temnodontosaurus (e.g. Hungerbühler \& Sachs 1996; Maisch \& Matzke 2000; McGowan \& Motani 2003). Moreover, phylogenetic ghost ranges imply the presence of numerous other lineages (those leading to Eurhinosaurus, Hauffiopteryx, Suevoleviathan, Malawania and Baracromia) in the Sinemurian (e.g. Caine \& Benton 2011; Fischer et al. 2013). We can preclude a leptonectid (Eurhinosaurus, Excalibosaurus or Leptonectes), Hauffiopteryx, or early baracromian origin for both SM 1976.1999.8 and NMS G. 2014.21.1 because these taxa have small, slender teeth with pointed apices, elongate crowns and little or no macroscopic enamel ornamentation (e.g. Maisch \& Matzke 2003; Maisch \& Reisdorf 2006; Maisch 2008; Caine \& Benton 2011). The Skye material cannot be referred to Suevoleviathan, as it lacks the thickened enamel ornamented with a 'bumpy' external texture that is diagnostic of this genus amongst Lower Jurassic ichthyosaurs (see Maxwell et al. 2012, table S4).

The deep ridges on the enamel continuing on to the root, present on the Skye specimens, are restricted to Ichthyosaurus and Temnodontosaurus (Vincent et al. 2014). However, the dentition of the Sinemurian Temnodontosaurus species (T. platyodon and T. eurycephalus) differs from SM 1976.1999.8 and NMS G. 2014.21.1. In T. eurycephalus the teeth are robust with little to no lingual curvature, are mediolaterally compressed and have apices that are either pointed or broken and roots that are bulbous (such that they are noticeably wider than at the crown-root junction) (pers. obs. of NHMUK PV R1157; McGowan 1974). The lack of carinae in the Skye specimens differs from T. eurycephalus, T. trigonodon and T. platyodon (Godefroit 1993; Martin et al. 2012), although this feature appears variable in the latter. The root is not swollen, unlike in Temnodontosaurus species for which teeth are known (although this is variable, ranging from being only slightly swollen to bulbous, as in T. eurycephalus) (McGowan 1974, 1994). Thus, these crown and root morphotypes of Temnodontosaurus do not match either SM 1976.1999.8 or NMS G. 2014.21.1.

Within the genus Ichthyosaurus, there are considered to be three (McGowan \& Motani 2003) or four valid Hettangian-Sinemurian species (e.g. Maisch \& Matzke 2000; Bennett et al. 2012). We can exclude both Skye specimens from I. intermedius (considered by McGowan \& Motani 2003 to be a subjective junior synonym of $I$. communis), as this taxon has 'waisted' dentition, namely a narrow crown and an inflated root, which gives the crown-root junction a 'stepped' appearance (Maisch \& Matzke 2000). The teeth of $I$. conybeari are described as being pointed, slender and 'high-crowned' (Maisch \& Matzke 2000), which does not match the morphology of SM 1976.1999.8. Additionally, I. conybeari is a small-bodied taxon (perhaps not exceeding $1.5 \mathrm{~m}$ in length; McGowan \& Motani 2003) and, as such, is too small to have dentition with roots $c .1 \mathrm{~cm}$ in diameter or tooth crowns several centimetres long like in the Skye specimens. The teeth of I. breviceps have pointed or broken apices and somewhat bulbous roots (Massare \& Lomax 2014). Moreover, the largest reported I. breviceps individual has a skull-to-tail bend length of $1.6 \mathrm{~m}$ (Massare
\& Lomax 2014), which is also too small to match the Skye teeth and mandible.

This leaves Ichthyosaurus communis. We consider this taxon to be the most likely candidate for SM 1976.1999.8 and NMS G. 2014.21.1, as the dental apomorphies of this species are found in both specimens. In particular, the tooth crowns of SM 1976.1999.8 are robust and have blunt apices, while the tooth root of NMS G. 2014.21.1 is textured by deep ridges, somewhat rectangular in cross-section and not bulbous. This combination of features is unique to I. communis (Vincent et al. 2014). However, keeping in mind the often variable nature of teeth, we conservatively refer these specimens to cf. Ichthyosaurus communis pending discovery of more complete material.

\section{ICHTHYOSAURIA indet. Figure 5s-t}

Material. NMS G. 2014.21.2: single incomplete vertebral centrum (Fig. $5 \mathrm{~s}-\mathrm{t}$ ).

Provenance. The specimen was collected during a 2013 field trip by one of the authors (S.L.B.). It was found loose on the foreshore of the section of coastline below the crofting village of Valtos (Trotternish Peninsula) at the type section for the Valtos Sandstone Formation (Fig. 1). From lithological comparison of the surrounding in situ units, the specimen most likely originates from the lower sandstonedominated unit of the Valtos Sandstone Formation (late Bajocian-early Bathonian).

Description. The vertebral centrum is very fragmentary, with only a portion of the ventral region preserved (Fig. $5 \mathrm{~s}-\mathrm{t}$ ). Either the anterior or posterior face is visible; it is strongly concave and has a semi-circular outline. The diapophyses are not preserved, but one of the parapophyses is. It is present as a poorly preserved process that clearly projects laterally away from the centrum. As the parapophysis is borne so far dorsally on the centrum, it is likely that this specimen is a cervical or anterior dorsal vertebra (see Andrews 1910; McGowan \& Motani 2003).

\section{ICHTHYOSAURIA indet.}

Material. GLAHM 152379: portion of the palatal process of a right pterygoid (Fig. 6).

Provenance. The specimen was found by David Cooper ex situ 'within yards of the boat slipway at Staffin' in the late 1980s (D. Cooper pers. comm. to D.A.R., 1995). Although the stratigraphic source of the specimen cannot be determined with certainty, the boat slipway at Staffin lies on rocks of the Duntulm Formation above horizons of Praeexogyra (mid-late Bathonian) (Fig. 1).

Description. Based upon comparisons with the pterygoids of Ichthyosaurus (Sollas 1916; McGowan 1973) and ophthalmosaurids (Andrews 1910; Kear 2005; Fischer et al. 2011), we consider GLAHM 152379 to be part of the palatal process (= anterior process) of a right pterygoid (Fig. 6). The process is broken anteriorly and posteriorly; it is thus incomplete and the main body of the pterygoid is not 

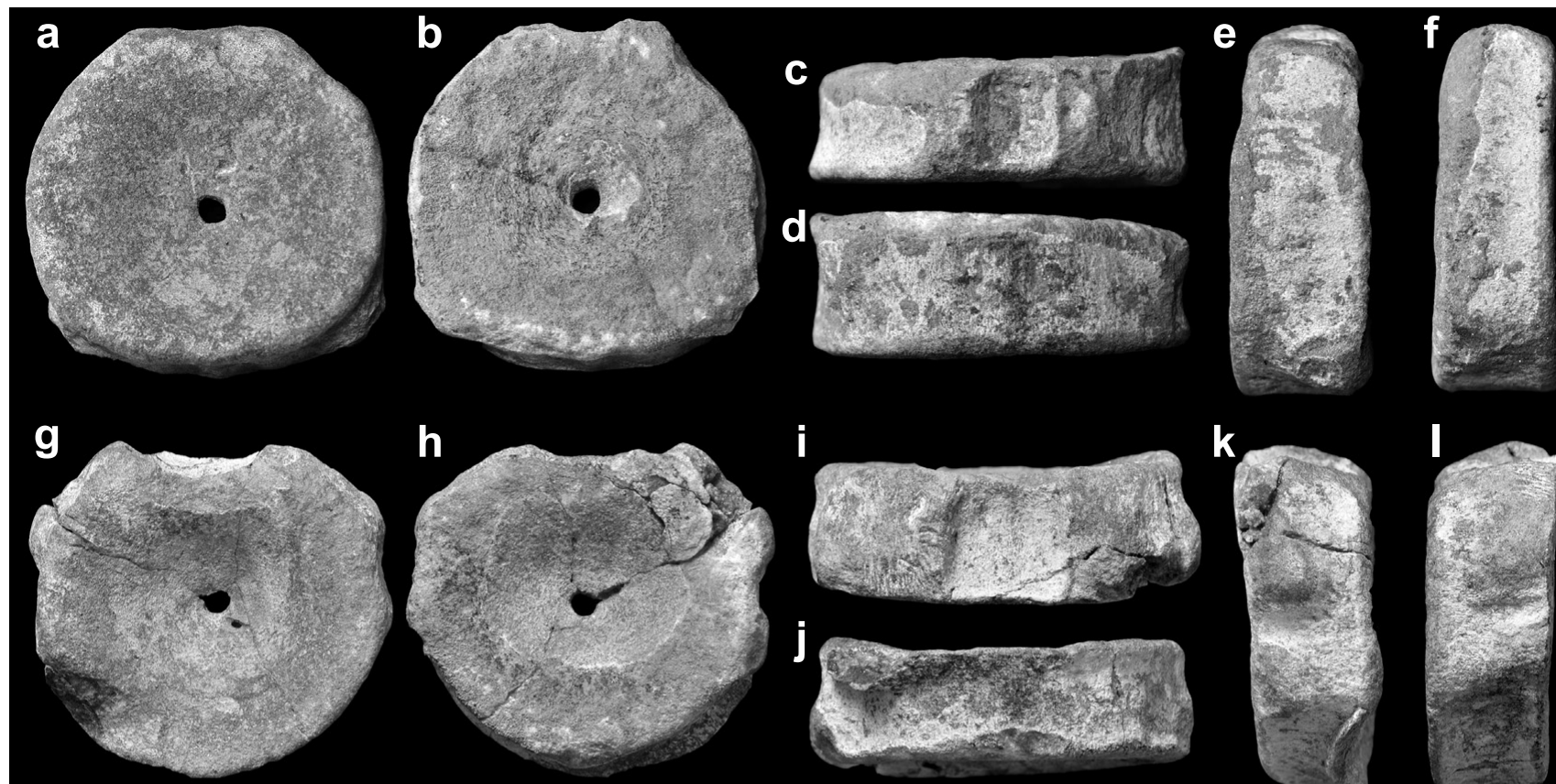

h
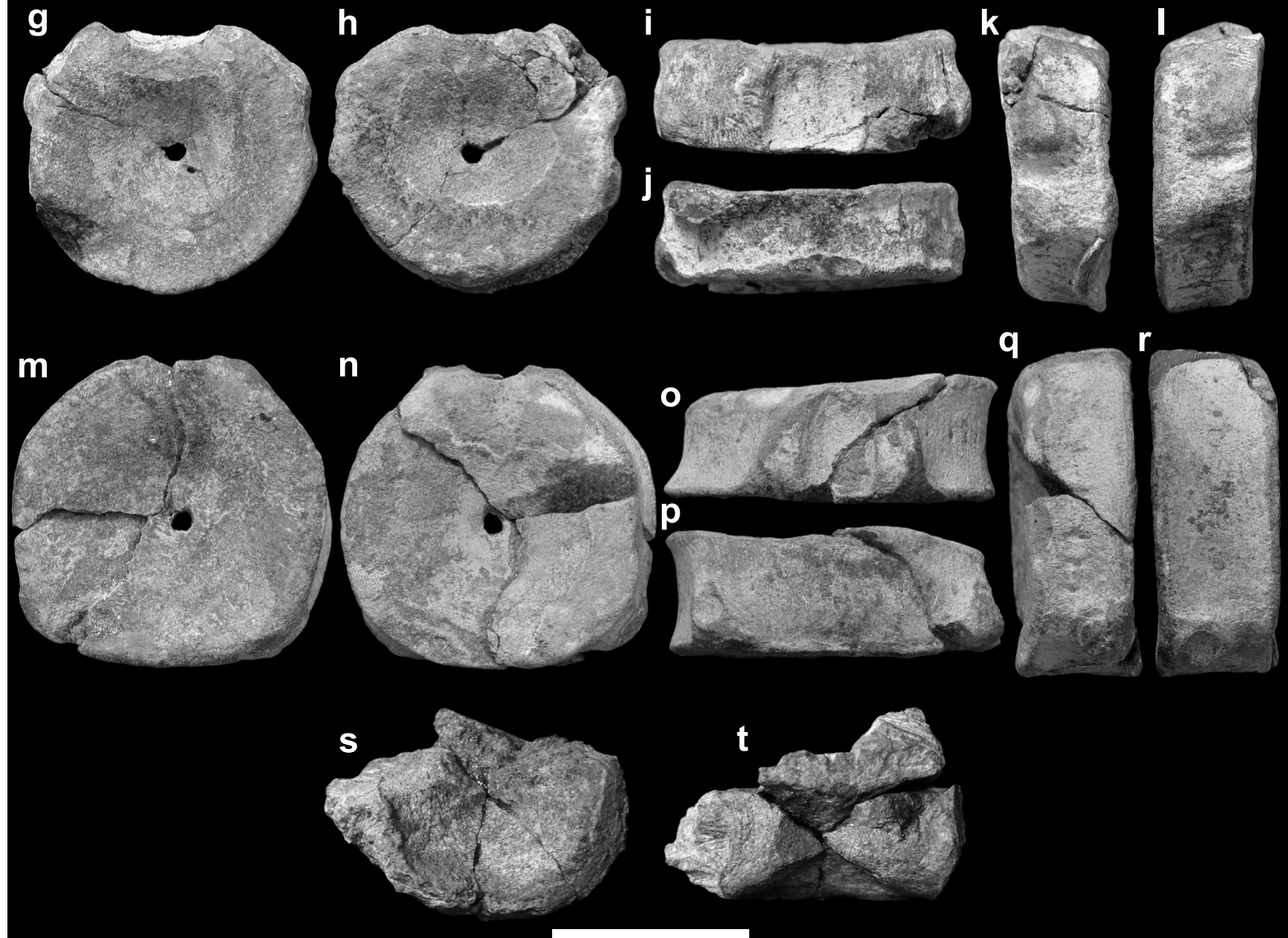

$3 \mathrm{~cm}$

Fig. 5. Ichthyosaur vertebrae from the Early-Middle Jurassic of Skye, Scotland. (a-r) Series of three associated vertebrae (Dearcmhara shawcrossi, gen. et sp. nov.) from the Early-Middle Jurassic Bearreraig Sandstone Formation (GLAHM 152378/2-4) in anterior, posterior, dorsal, ventral and lateral views: (a-f, $\mathrm{m}-\mathrm{r})$ anterior caudal centra; $(\mathrm{g}-\mathrm{l})$ anterior dorsal centra. (s-t) Isolated ichthyosaur vertebra from the Middle Jurassic Valtos Sandstone Formation (NMS G. 2014.21.1) in (s) anterior and (t) dorsal views.

preserved. The anterior breakage means that the symphyseal suture for the left pterygoid is missing. In cross-section the process is sub-rectangular, with the dorsal lamella having a sub-triangular cross-section ventrally, until it becomes lamellar in the middle-dorsal regions. The dorsal lamella is broken along its dorsal margin, and has experienced postmortem deformation resulting in it being strongly deflected medially. At the posterolateral margin of the palatal process there is an articulation facet for the posterior ramus of the vomer (Fig. 6b). Due to the poor preservation along the lateral margin, it is difficult to discern the nature of the contact with the palatine, although based on other ichthyosaurs, the palatine would have overlapped the lateral margin of the palatal process along with the vomer (e.g. Sollas 1916; Kear 2005). Along the dorsal margin, immediately medial to the dorsal lamella, there is a wide, shallow, longitudinal depression. This would have been for the articulation with the cultriform process of the parabasisphenoid.

\section{NEOICHTHYOSAURIA Sander 2000}

Dearcmhara shawcrossi gen. et sp. nov. Figures 5, 7

Etymology. Dearcmhara, Scottish Gaelic for 'marine lizard'; shawcrossi, in honour of Brian Shawcross, who collected the specimens and magnanimously donated them to a museum collection instead of retaining them in private 


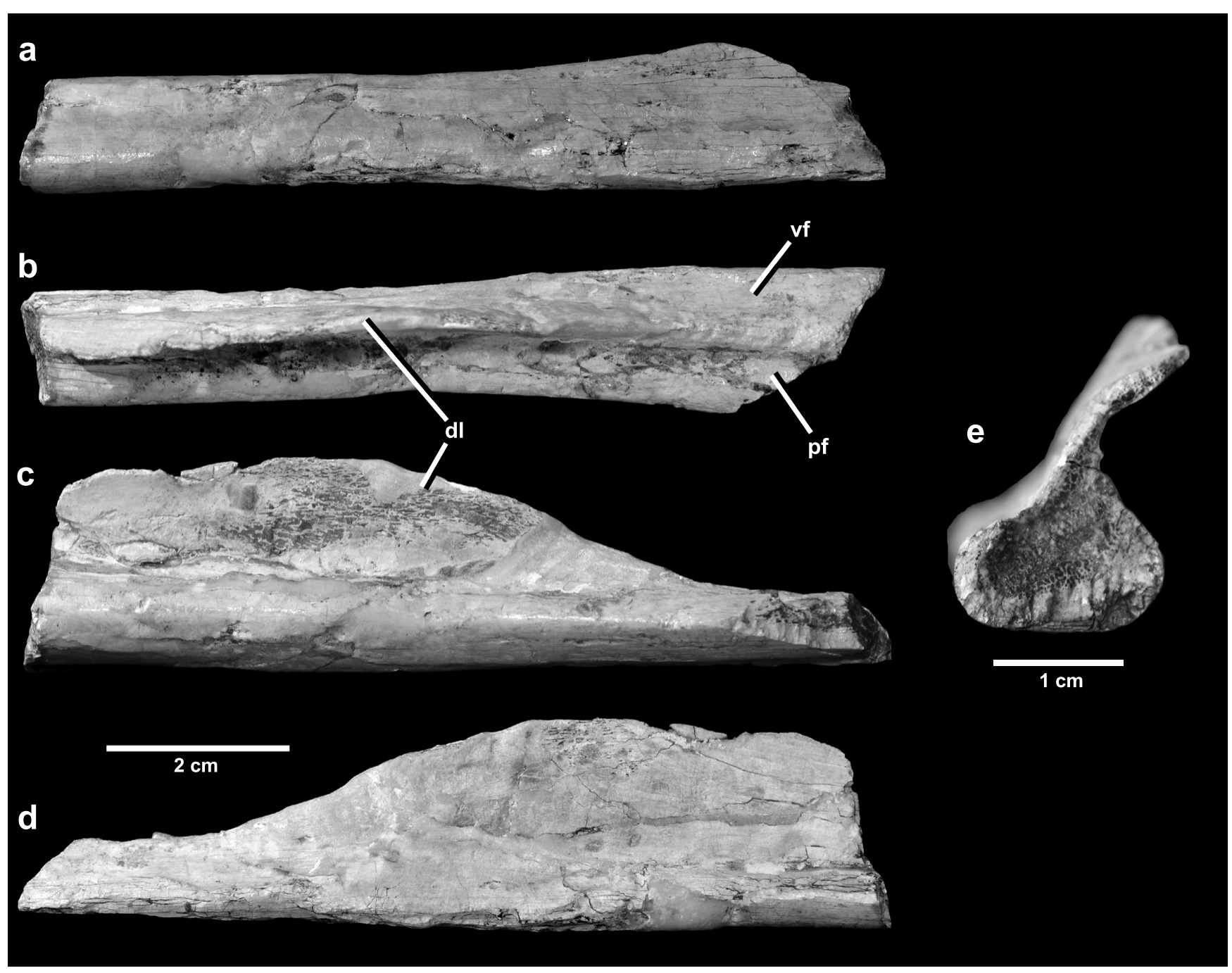

Fig. 6. Fragment of the anterior portion of a right ichthyosaur pterygoid from the Middle Jurassic (Bathonian) Duntulm Formation of Skye, Scotland (GLAHM 152379) in (a) ventral, (b) dorsal, (c) medial, (d) lateral and (e) anterior views. Abbreviations: dl, dorsal lamella; pf, parasphenoid facet; vf, vomer facet. Scale bars: (a-d) $2 \mathrm{~cm}$; (e) $1 \mathrm{~cm}$.

hands. In English phonology Dearcmhara is pronounced as 'jark vara' (IPA for Scottish English Phonology: đzerk vere). Note that in other English phonologies the open vowel (i.e. 'a') can be pronounced differently, and the alveolar trill ('rolled r') is the alveolar approximant (I).

Holotype. GLAHM 152378/1-4. An associated distal humerus (GLAHM 152378/1; Fig. 7) and three vertebrae (GLAHM 152378/2-4; Fig. 5a-r), including one anterior dorsal centrum (GLAHM 152378/3) and two anterior caudal centra (GLAHM 152378/2 and 4). The specimens were found associated but in the eventuality that later research determines that they belong to different taxa, the humerus is designated as the name-bearing holotype of Dearcmhara shawcrossi.

Provenance. The specimens were recovered ex situ, but in association, from Bearreraig Bay by Brian Shawcross in or around 1959 (Fig. 1). It is likely that the specimens originate from the Bearreraig Sandstone Formation, assuming that the specimens were not transported to Bearreraig Bay from elsewhere by longshore drift (which we consider unlikely due to their associated nature and lack of strong abrasion, as well-preserved associated specimens are incredibly rare on Skye). The most accurate age for this formation is late
Toarcian-late Lower Bajocian ( $P$. aalensis-S. humphriesianum Zones).

Diagnosis. Basal neoichthyosaurian ichthyosaur with the following unique combination of characters, with autapomorphies among basal neoichthyosaurians indicated with an asterisk (all on the humerus): presence of an anterodistal leading edge facet (shared with Temnodontosaurus and Leptonectidae, although this facet is variably present within both clades); a deep concavity within the leading edge of the anterodistal facet*; large and triangular supraulnar process*; waisted humeral shaft, with the leading edge having a pronounced concavity, whereas the posterior edge is much more weakly concave (shared with Temnodontosaurus and Excalibosaurus); in lateral view, the distal margin of the ulnar facet is strongly concave, whereas the distal margin of the radial facet is straight to weakly convex (shared with Temnodontosaurus, but this morphology is variable within Leptonectidae).

Description. Vertebral column differentiation is somewhat poorly understood in ichthyosaurs because the pectoral and pelvic girdles are rarely found in articulation with the vertebral column. A commonly accepted framework is used for 


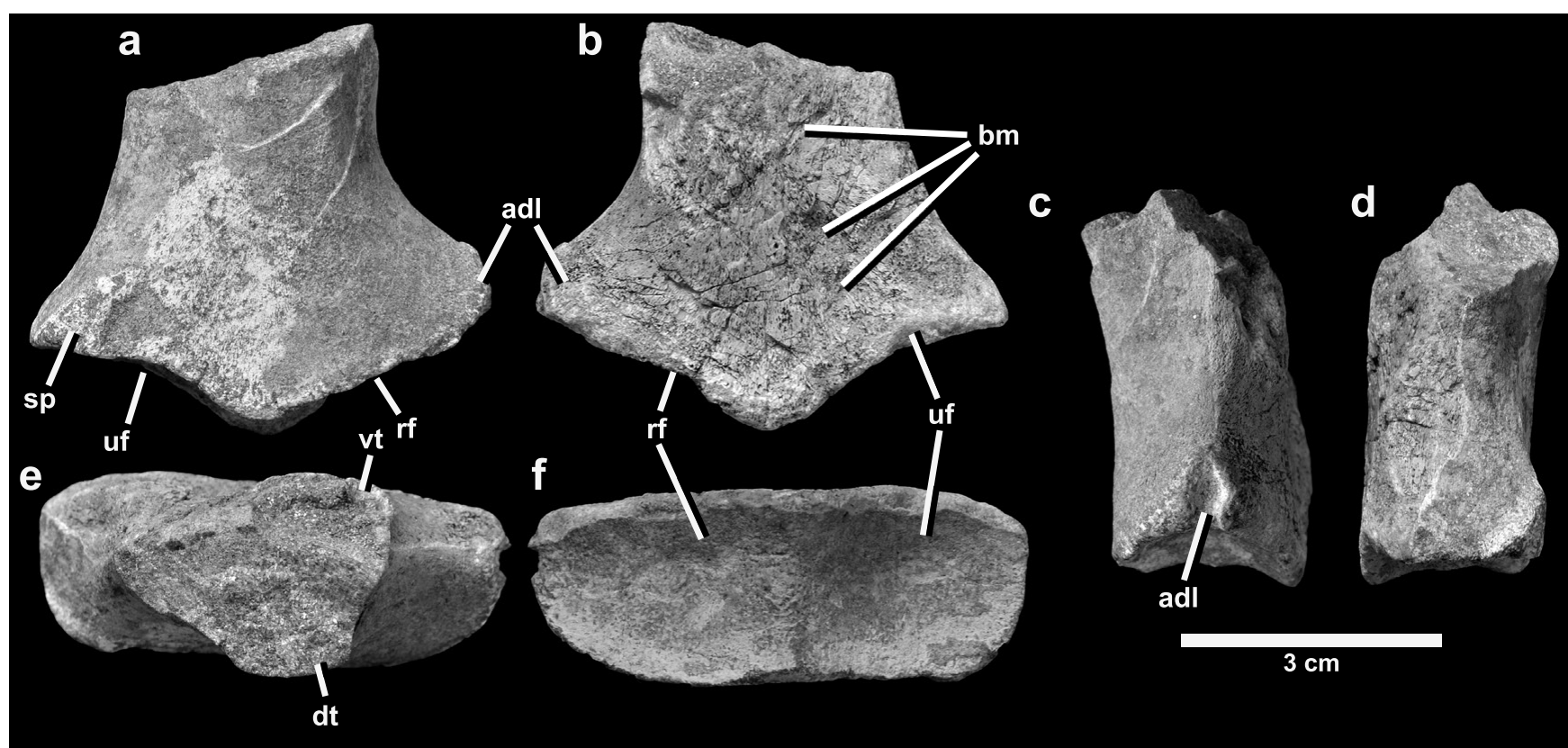

Fig. 7. A neoichthyosaurian humerus (Dearcmhara shawcrossi gen. et sp. nov.) from the Early-Middle Jurassic (Toarcian-Bajocian) Bearreraig Sandstone Formation of Skye, Scotland (GLAHM 152378/1) in (a) dorsal, (b) ventral, (c) anterior, (d) posterior, (e) proximal and (f) distal views. Abbreviations: adl, anterodistal leading edge facet; bm, bite marks; dt, dorsal trochanter; rf, radial facet; sp, supraulnar process; uf, ulnar facet; vt, ventral trochanter.

descriptions of thunnosaurian vertebrae (see Andrews 1910; McGowan \& Motani 2003; Kolb \& Sander 2009; Fischer et al. 2011). In this framework cervical centra have the diapophyses fused to the facet for the neural arch, the anterior dorsal centra have separated diapophyses and parapophyses which are both on the upper half of the centrum. The posterior dorsal centra have separate diapophyses and parapophyses which are located on the lower half of the centrum, the anterior caudal centra have a single lateroventrally orientated apophysis, and the mid-caudal and postflexural centra are typically laterally compressed and have chevron facets on their ventral surfaces.

Based upon this framework, there is one anterior dorsal centrum (Fig. 5g-i) and two anterior caudal centra (Fig. 5a-f, m-r) present in GLAHM 152378/1-4. All three centra are amphicoelous, although the anterior dorsal centrum has noticeably more concave anterior and posterior faces than the two caudal centra. At the centre of these concavities, there is a perforation in all three centra, suggesting that the individual is not fully grown (e.g. O'Keefe et al. 2009). The ventral surface of all three centra lacks a hypophysis. The anterior dorsal centrum lacks the extensive posterolateral lamellae seen in Acamptonectes dorsal centra (Fischer et al. 2012). The neural canal is noticeably wider on the anterior dorsal centrum than on the two caudal centra. Additionally, the shape of the anterior and posterior centra surfaces differs between the dorsal and caudal centra. The dorsal centrum has a semi-circular ventral half, whereas the dorsal half is noticeably less rounded. In contrast, the caudal centra have a semi-circular dorsal half, whereas the ventral half is less rounded, having an almost straight ventral surface. The centrum height-to-length ratio of the anterior dorsal vertebra is 2.74, whereas the ratio in the anterior caudals is 2.65 (GLAHM 152378/4) and 2.63 (GLAHM 152378/2).

As mentioned by McGowan \& Motani (2003: pp. 16-17) isolated vertebrae, and their shape variation, are to be used taxonomically with caution. This is due to only a limited number of species being known from complete skeletons, which if available are typically viewable in only one aspect. As there are no listed centra apomorphies for ichthyosaurian subclades, they do not on their own help identify which clade GLAHM 152378/1-4 belongs to.

The humerus is complete distally but lacks the proximal region. The ventral surface is poorly preserved and somewhat damaged (Fig. 7b), thus partially obscuring what remains of the ventral trochanter. In proximal view, however, the trochanter can be seen as a sub-rectangular 'curve' orientated slightly anteriorly along the ventral margin (Fig. $7 \mathrm{e})$. The dorsal surface is much better preserved, with the distal end of the dorsal trochanter visible (Fig. 7a). In proximal view, this trochanter can be seen along the dorsal margin of the bone; it is wide and flat (Fig. 7e). The humeral shaft is distinctly waisted, formed by the leading edge having a pronounced concavity, whereas the posterior edge is more poorly concave (shared with Temnodontosaurus and Excalibosaurus; McGowan 1994, 2003; McGowan \& Motani 2003; Martin et al. 2012).

One of the most distinctive features of the humerus is an anterodistal facet along the leading edge, which houses a small, deep concavity that is sub-oval in shape (Fig. 7c, adl). The leading edge facet is seen in Temnodontosaurus and Leptonectidae (McGowan \& Milner 1999; McGowan 2003; McGowan \& Motani 2003; Martin et al. 2012), but we have not observed a deep concavity within the facet in any other ichthyosaurs. Therefore, the concavity is regarded as an autapomorphy of Dearcmhara shawcrossi.

Along the distal surface there are two very large, deeply concave, sub-rectangular facets for the radius and ulna. The radial facet is orientated anterodistally, whereas the ulnar facet is orientated posterodistally. The radial and ulnar facets are separated by a wide, low-relief, gently convex ridge on the distal surface of the bone. The leading edge and radial 
facets are on different surfaces, and the ridge separating them is also of low-relief and gently convex. There is no posterior accessory facet. In lateral view, the distal margin of the ulnar facet is strongly concave, whereas the distal margin of the radial facet is straight to weakly convex. This marked difference between the facets is also seen in Temnodontosaurus (McGowan 1994; McGowan \& Motani 2003; Martin et al. 2012). However, in leptonectids the distal margins of the radial and ulnar facets can be variable (McGowan \& Milner 1999; McGowan 2003).

Another distinctive feature of the bone is seen in lateral view. Immediately proximal to the ulnar facet (at the posterodistal edge of the humerus) there is a large triangular process (herein called the supraulnar process) that projects in relief from the bone surface (Fig. 7a, sp). Both the large size and triangular shape make it distinct from other neoichthyosaurians, as other specimens (as exemplified, for example, by the ophthalmosaurids Sveltonectes and Sisteronia: Fischer et al. 2011, 2014) have at most a 'bulge' proximal to the posterior third of the ulnar facet, which is never as pronounced in relief or a distinct triangular shape. Therefore, the enlarged, strongly offset triangular supraulnar process is an autapomorphy of Dearcmhara shawcrossi.

The humeral medial surface shows evidence of predation and/or scavenging (Fig. 7b, bm), with one distinct tooth mark level where the shaft begins to narrow. Interestingly, there appears to be numerous longitudinal marks across this surface (one particularly deep mark is orientated anterodistally to posteroproximally), which could represent damage caused by tooth apices. As there is no sign of remodelling around these bite marks, it suggests they occurred either peri- or post-mortem.

The combination of a distinctly waisted humerus with a prominent anterodistal leading edge characterizes non-thunnosaurian neoichthyosaurs (Motani 1999; Martin et al. 2012). The conditions seen in GLAHM 152378/1-4 appear especially similar to those of Leptonectes spp., Temnodontosaurus trigonodon and Temnodontosaurus azerguensis (McGowan 1996; Motani 1999; Martin et al. 2012; Vincent et al. 2014). The anterodistal leading edge tuberosity is marked in the basal neoichthyosaurian taxa Leptonectidae and some species of Temnodontosaurus; it is present but not prominent in Suevoleviathan (see Maisch 1998) and seemingly disappears in Thunnosauria (see distribution of character 44 in Fischer et al. 2013; it may be present but small and rounded in Hauffiopteryx Caine \& Benton 2011). The available evidence, therefore, strongly suggests that GLAHM 152378/1-4 is a non-thunnosaurian neoichthyosaurian. Within this grade of ichthyosaurs, and among all ichthyosaurs more broadly, the autapomorphic presence of a deep concavity within the anterodistal leading edge facet and the large and triangular supraulnar process support the referral of GLAHM 152378/1-4 to a new taxon, Dearcmhara shawcrossi.

The humerus of Dearcmhara shawcrossi is superficially similar to those of ophthalmosaurids in some regards, but an ophthalmosaurid identity can be ruled out. Based on the unambiguous character optimizations in the phylogenetic analysis of Fischer et al. (2012), Ophthalmosauridae has two humeral synapomorphies: a plate-like dorsal trochanter (character 30), and a facet for an anterior accessory element (character 33, although there is a reversal in Fischer et al.'s (2012) clade 'B'). GLAHM 152378/1-4 clearly lacks a facet for an anterior accessory epipodial element, and appears to lack the plate-like trochanter (instead, the distal preserved portion of the trochanter is wide and flat), indicating that the specimen cannot be referred to Ophthalmosauridae.

\section{Discussion}

The specimens described here are the first ichthyosaurs from Skye, and Scotland more broadly, described and figured in detail in the scientific literature. Although many of these specimens are fragmentary, they are all diagnostically ichthyosaurian, and demonstrate that ichthyosaurs were present in Mesozoic Scotland for a long time. The specimens span from the Sinemurian to the Bathonian, indicating that ichthyosaurs were present in Scotland from, at the very least, approximately 199-166 Ma. It is likely that ichthyosaurs were a common and important component of Scottish marine ecosystems during most of the Jurassic, and perhaps beyond.

The oldest material described here, from the Sinemurian (Early Jurassic, c. 199-196 Ma), may pertain to the characteristic taxon Ichthyosaurus communis (based on dental features). If correct, then to our knowledge the Skye material represents the most northerly occurrence of this geographically widespread ichthyosaur. Ichthyosaurus communis is abundant in the Lower Jurassic deposits of Lyme Regis and surrounding areas of England, and was evidently a major component of this most famous of marine reptile faunas. The presence of I. communis in Skye would perhaps suggest that Scotland was also home to a characteristic Lyme Registype vertebrate fauna during the Early Jurassic.

The distal humerus and associated vertebral centra from the Toarcian-Bajocian (c. 177-169 Ma) represents a new basal neoichthyosaurian taxon, which we herein name Dearcmhara shawcrossi. This specimen contributes to a growing body of evidence that aids understanding of the origin of Ophthalmosauridae and their rise to dominance at the expense of more basal neoichthyosaurians. Ophthalmosauridae evolved from Stenopterygius-like baracromians during the Aalenian (Fischer et al. 2011, 2013). Both the sister taxon of Ophthalmosauridae (Stenopterygius/Chacaicosaurus cayi from the early Bajocian) and the earliest record of Ophthalmosauridae (at the Aalenian-Bajocian boundary) are located in South America (Fernández 1994, 2003). Ophthalmosaurinae, an ophthalmosaurid subfamily, is already present in the early Bajocian of Canada (Druckenmiller \& Maxwell 2014), suggesting that Ophthalmosauridae rapidly radiated along western Gondwanan margins at the onset of the Middle Jurassic. In contrast, Upper Toarcian-Aalenian ichthyosaur assemblages were somewhat different in Europe, as their record consists entirely of non-ophthalmosaurid neoichthyosaurians (Maxwell et al 2012; Vincent et al. 2013). Following the middle Callovian, however, ophthalmosaurids are the only ichthyosaurs recorded in Europe (e.g. McGowan \& Motani 2003). The critical shift from a basal neoichthyosaurian-only to an ophthalmosaurid-only assemblage thus took place between the late Aalenian-early Callovian, when the fossil record is extremely poor. The Skye ichthyosaur falls within this critical gap and may be 
the youngest known non-ophthalmosaurid in Europe. As such, it provides further evidence that the rise of ophthalmosaurids was delayed in Europe relative to other parts of the world, particularly Gondwana.

It may seem surprising that the fossils reported here are the first Scottish ichthyosaur specimens to be comprehensively described. Several other marine reptile specimens have been mentioned in the literature (e.g. Lee \& Buckman 1920; Arkell 1933; Hudson 1966; Hudson \& Morton 1969; Martill 1985; Benton et al. 1995; Page \& Wimbledon 2008), but the whereabouts of many of these fossils are currently unclear. A handful of Skye ichthyosaur specimens are accessioned into the collections of National Museums Scotland and the Hunterian Museum and await further preparation and study. Most material, however, has apparently been privately collected and has since disappeared from the scientific record, with little or no information on current whereabouts, ownership, or accessibility. This is an unfortunate situation that has developed over the past several decades and one that we hope will change, as fossil vertebrate specimens from Skye and elsewhere are the rare and irreplaceable natural heritage of Scotland, providing the only information on what prehistoric creatures lived in Scotland during the Age of Dinosaurs. We are pleased that some of the specimens described here were collected by amateurs and donated to museum collections, including the holotype of an important new genus and species that would have been lost to science had it remained in private hands. We are honoured to name this new animal after Brian Shawcross, the collector who so generously donated the material to the Hunterian Museum. As so much about Scotland's prehistoric past remains to be discovered, we look forward to working together with amateur collectors to preserve important fossil discoveries and paint a clearer picture of what Scotland was like when dinosaurs thundered across the land and marine reptiles dominated the oceans.

\section{Acknowledgements and Funding}

We thank all collectors who have donated the specimens described here to museum collections, particularly Brian Shawcross. Their generosity ensures that these fossils - Scotland's irreplaceable heritage - are preserved for posterity. We thank Vicen Carrió at NMS for specimen preparation, Dean Lomax and Benjamin Moon for discussions on ichthyosaur anatomy, Al McGowan for discussion on Scottish fossils, and the reviewers (Erin Maxwell and Michael Benton) and editor (Breandán MacGabhann) for their helpful comments that improved this paper. SLB, TJC, and MW thank the University of Edinburgh, School of GeoSciences for funding their 2013 field trip, Maikki Haapalainen for field assistance, and Alex Turner of SNH for help with logistics and permissions.

\section{Scientific editing by Alastair MacGowan}

\section{References}

Andrews, C.W. 1910. A Descriptive Catalogue of the Marine Reptiles of the Oxford Clay, Part One. British Museum (Natural History), London.

Andrews, J.E. 1986. Microfacies and geochemistry of Middle Jurassic algal limestones from Scotland. Sedimentology, 33, 499-520.

Andrews, J.E. \& Hudson, J.D. 1984. First Jurassic dinosaur footprint from Scotland. Scottish Journal of Geology, 20, 129-134.

Anquetin, J., Barrett, P.M., Jones, M.E.H., Moore-Fay, S. \& Evans, S.E. 2009. A new stem turtle from the Middle Jurassic of Scotland: New insights into the evolution and palaeoecology of basal turtles. Proceedings of the Royal Society of London Series B, 276, 879-886.

Arkell, W.J. 1933. The Jurassic System in Great Britain. Oxford University Press, Oxford.

Barrett, P.M. 2006. A sauropod dinosaur tooth from the Middle Jurassic of Skye, Scotland. Transactions of the Royal Society of Edinburgh: Earth Sciences, 97, 25-29.

Bennett, S.P., Barrett, P.M., Collinson, M.E., Moore-Fay, S., Davis, P.G. \& Palmer, C.P. 2012. A new specimen of Ichthyosaurus communis from
Dorset, UK, and its bearing on the stratigraphical range of the species. Proceedings of the Geologists' Association, 123, 146-154.

Benton, M.J. \& Spencer, P.S. 1995. Fossil Reptiles of Great Britain. Geological Conservation Review Series, No. 10. Chapman and Hall, London.

Benton, M.J., Martill, D.M. \& Taylor, M.A. 1995. The first Lower Jurassic dinosaur from Scotland: Limb bone of a ceratosaur theropod from Skye. Scottish Journal of Geology, 31, 177-182.

Blainville, H.M.D. de 1835. Description de quelques espèces de reptiles de la Californie, précédé de l'analyse d'un système general d'erpétologie et d'amphibiologie. Nouvelles Annales du Muséum d'Histoire Naturelle, Paris, 4, 233-296.

Caine, H. \& Benton, M.J. 2011. Ichthyosauria from the Upper Lias of Strawberry Bank, England. Palaeontology, 54, 1069-1093.

Chen, P.-J. \& Hudson, J.D. 1991. The conchostracan fauna of the Great Estuarine Group, Middle Jurassic, Scotland. Palaeontology, 34, 515-545.

Clark, N.D.L. 2001. A thyreophoran dinosaur from the early Bajocian (Middle Jurassic) of the Isle of Skye, Scotland. Scottish Journal of Geology, 37, 19-26.

Clark, N.D.L. \& Barco Rodríguez, J.I. 1998. The first dinosaur trackway from the Valtos Sandstone Formation (Bathonian, Jurassic) of the Isle of Skye, Scotland, UK. Geogaceta, 24, 79-82.

Clark, N.D.L., Nimmo, F. \& Nicholas, C.J. 1993. A new occurrence of Scottish plesiosaurian remains from the Isle of Skye. Scottish Journal of Geology, 29, 197-199.

Clark, N.D.L., Boyd, J.D., Dixon, R.J. \& Ross, D.A. 1995. The first Middle Jurassic dinosaur from Scotland: A cetiosaurid? (Sauropoda) from the Bathonian of the Isle of Skye. Scottish Journal of Geology, 31, 171-176.

Clark, N.D.L., Booth, P., Booth, C. \& Ross, D.A. 2004. Dinosaur footprint from the Duntulm Formation (Bathonian, Jurassic) of the Isle of Skye. Scottish Journal of Geology, 40, 13-21.

Clark, N.D.L., Ross, D.A. \& Booth, P. 2005. Dinosaur tracks from the Kilmaluag Formation (Bathonian, Middle Jurassic) of Score Bay, Isle of Skye, Scotland, UK. Ichnos, 12, 93-104.

Conybeare, W.D. 1822. Additional notices on the fossil genera Ichthyosaurus and Plesiosaurus. Transactions of the Geological Society of London, 1, 103-123.

Cox, B.M. \& Sumbler, M.G. 2002. British Middle Jurassic Stratigraphy. Geological Conservation Review Series, No. 26. Joint Nature Conservation Committee, Peterborough.

De La Beche, H.T. \& Conybeare, W.D. 1821. Notice of the discovery of a new fossil animal, forming a link between the Ichthyosaurus and the Crocodile, together with general remarks on the Osteology of the Ichthyosaurus. Transactions of the Geological Society of London, 5, 559-594.

Druckenmiller, P.S. \& Maxwell, E.E. 2014. A Middle Jurassic (Bajocian) ophthalmosaurid (Reptilia, Ichthyosauria) from the Tuxedni Formation, Alaska and the early diversification of the clade. Geological Magazine, 151, 41-48.

Evans, S.E. \& Milner, A.R. 1994. Microvertebrate faunas from the Middle Jurassic of Britain. In: Fraser, N.C. \& Sues, H.-D. (eds) In The Shadow of the Dinosaurs. Cambridge University Press, Cambridge, 303-321.

Evans, S.E., Barrett, P.M., et al. 2006. The Middle Jurassic vertebrate assemblage of Skye, Scotland. Ninth International Symposium on Mesozoic Terrestrial Ecosystems and Biota, 2009, 26-39.

Fernández, M. 1994. A new long-snouted ichthyosaur from the early Bajocian of Neuquén basin (Argentina). Ameghiniana, 31, 291-297.

Fernández, M. 2003. Ophthalmosauria (Ichthyosauria) forefin from the Aalenian-Bajocian boundary of Mendozo Province, Argentina. Journal of Vertebrate Paleontology, 23, 691-694.

Fischer, V., Masure, E., Arkhangelsky, M.S. \& Godefroit, P. 2011. A new Barremian (Early Cretaceous) ichthyosaur from western Russia. Journal of Vertebrate Paleontology, 31, 1010-1025.

Fischer, V., Maisch, M.W., et al. 2012. New ophthalmosaurid ichthyosaurs from the European Lower Cretaceous demonstrate extensive ichthyosau survival across the Jurassic-Cretaceous Boundary. PLOS ONE, 7, e29234.

Fischer, V., Appleby, R.M., Naish, D., Liston, J., Riding, J.B., Brindley, S. \& Godefroit, P. 2013. A basal thunnosaurian from Iraq reveals disparate phylogenetic origins for Cretaceous ichthyosaurs. Biology Letters, 9, 20130021.

Fischer, V., Bardet, N., Guiomar, M. \& Godefroit, P. 2014. High diversity in Cretaceous ichthyosaurs from Europe prior to their extinction. PLOS ONE, 9, e84709.

Godefroit, P. 1993. Les grands ichthyosaures sinémuriens d'Arlon. Bulletin de l'Institut Royal des Sciences Naturelles de Belgique Sciences de la Terre, 63, 25-71.

Godefroit, P. 1996. Un crâne d'Ichthyosaurus communis (Reptilia, Ichthyosauria) du Sinémurien supérieur de Lorrain belge. Bulletin de la Société belge de géologie, 104, 77-90.

Hallam, A. 1959. Stratigraphy of the Broadford Beds of Skye, Raasay and Applecross. Proceedings of the Yorkshire Geological and Polytechnic Society, 32, 165-184

Harris, J.P. 1992. Mid-Jurassic lagoonal delta systems in the Hebridean basins: Thickness and facies distribution patterns of potential reservoir sandbodies. In: Parnell, J. (ed.) Basins on the Atlantic Seaboard: Petroleum Geology, Sedimentology and Basin Evolution. Geological Society, London, Special Publications, 62, 111-144, http://dx.doi.org/10.1144/GSL SP.1992.062.01.11

Hesselbo, S.P. 2008. Sequence stratigraphy and inferred relative sea-level change from the onshore British Jurassic. Proceedings of the Geologists Association, 119, 19-34. 
Hesselbo, S.P. \& Coe, A.L. 2000. Jurassic sequences of the Hebrides Basin, Isle of Skye, Scotland. In: Graham, J.R. \& Ryan, A. (eds) Field Trip Guidebook, International Sedimentologists Association Meeting, Dublin, 41-58.

Hesselbo, S.P., Oates, M.J. \& Jenkyns, H.C. 1998. The lower Lias of the Hebrides Basin. Scottish Journal of Geology, 34, 23-60.

Hudson, J.D. 1966. Hugh Miller's Reptile Bed and the Mytilus Shales, Middle Jurassic, Isle of Eigg, Scotland. Scottish Journal of Geology, 2, 265-281.

Hudson, J.D. 1970. Algal limestones with pseudomorphs after gypsum from the Middle Jurassic of Scotland. Lethaia, 3, 11-40.

Hudson, J.D. \& Andrews, J.E. 1987. The diagenesis of the Great Estuarine Group, Middle Jurassic, Inner Hebrides, Scotland. In: Marshall, J. D. (ed.) Diagenesis of Sedimentary Sequences. Geological Society, London, Special Publications, 36, 259-276.

Hudson, J.D. \& Morton, N. 1969. Excursion Guide no. 4. International Field Symposium of the British Jurassic. Geology Department Keele University, Keele.

Hungerbühler, A. \& Sachs, S. 1996. Ein großer Ichthyosaurier aus dem Pliensbachium von Bielefeld. Neue Einblicke in die Ichthyosaurier des Mittleren Lias und das Gebiß von Temnodontosaurus. Bericht des Naturwissenschaftlichen Vereins Bielefeld und Umgegend, 37, 15-52.

Kear, B.P. 2005. Cranial morphology of Platypterygius longmani Wade, 1990 (Reptilia: Ichthyosauria) from the Lower Cretaceous of Australia. Zoological Journal of the Linnean Society, 145, 583-622.

Kolb, C. \& Sander, P.M. 2009. Redescription of the ichthyosaur Platypterygius hercynicus (Kuhn 1946) from the Lower Cretaceous of Salzgitter (Lower Saxony, Germany). Palaeontographica Abteilung A (Paläozoologie, Stratigraphie), 288, 151-192.

Laurenti, J.N. 1768. Specimen Medicum, Exhibens Synopsin Reptilium Emendatam cum Experimentis circa Venena. Viennae, Typ. Joan. Thomae nob. de Trattnern

Lee, G.W. \& Buckman, S.S. 1920. The Mesozoic Rocks of Applecross, Raasay, and North-East Skye. Memoirs of the Geological Survey, Scotland, Edinburgh.

Liston, J.J. 2004. A re-examination of a Middle Jurassic sauropod limb bone from the Bathonian of the Isle of Skye. Scottish Journal of Geology, 40, $119-122$.

MacFadyen, C.C.J. 1997. The Jurassic Sites of Special Scientific Interest on Skye \& Raasay. Scottish Natural Heritage Earth Science Site Documentation Report, No. 302

Maisch, M.W. 1998. A new ichthyosaur genus from the Posidonia Shale (Lower Toarcian, Jurassic) of Holzmaden, SW-Germany with comments on the phylogeny of post-Triassic ichthyosaurs. Neues Jahrbuch für Geologie und Paläontologie, Abhandlungen, 209, 47-78.

Maisch, M.W. 2008. Revision der Gattung Stenopterygius Jaekel, 1904 emend. von Huene, 1922 (Reptilia: Ichthyosauria) aus dem unteren Jura Westeuropas. Palaeodiversity, 1, 227-271.

Maisch, M.W. \& Matzke, A.T. 2000. The Ichthyosauria. Stuttgarter Beiträge zur Naturkunde, Serie B (Geologie und Paläontologie), 298, 1-159.

Maisch, M.W. \& Matzke, A.T. 2003. The cranial osteology of the ichthyosaur Leptonectes cf. tenuirostris from the Lower Jurassic of England. Journal of Vertebrate Paleontology, 23, 116-127.

Maisch, M.W. \& Reisdorf, A.G. 2006. Evidence for the longest stratigraphic range of a post Triassic Ichthyosaur: A Leponectes tenuirostris from the Pliensbachian (Lower Jurassic) is Switzerland. Geobios, 39, 491-505.

Maisch, M.W., Reisdorf, A.G., Schlatter, R. \& Wetzel, A. 2008. A large skull of Ichthyosaurus (Reptilia: Ichthyosauria) from the Lower Sinemurian (Lower Jurassic) of Frick (NW Switzerland). Swiss Journal of Geoscience, 101, 617-627.

Marshall, P. 2005. Theropod dinosaur and other footprints from the Valtos Sandstone Formation (Bathonian, Middle Jurassic) of the Isle of Skye. Scottish Journal of Geology, 41, 97-104.

Martill, D.M. 1985. Plesiosaur discovery in Scotland. Geology Today, 162

Martin, J.E., Fischer, V., Vincent, P. \& Suan, G. 2012. A longirostrine Temnodontosaurus (Ichthyosauria) with comments on Early Jurassic ichthyosaur niche partitioning and disparity. Palaeontology, 55, 995-1005.

Massare, J.A. \& Lomax, D.R. 2014. An Ichthyosaurus breviceps collected by Mary Anning: New information on the species. Geological Magazine, 151, 21-28.

Matyja, B.A., Wierzbowski, A. \& Wright, J.K. 2005. The Sub-Boreal/ Boreal ammonite succession at the Oxfordian/Kimmeridgian boundary at Flodigarry, Staffin Bay (Isle of Skye), Scotland. Transactions of the Royal Society of Edinburgh: Earth Sciences, 96, 387-405.

Maxwell, E.E., Fernández, M.S. \& Schoch, R.R. 2012. First diagnostic marine reptile remains from the Aalenian (Middle Jurassic): A new ichthyosaur from southwestern Germany. PLoS ONE, 7, e41692.

McGowan, C. 1973. The cranial morphology of the Lower Liassic latipinnate ichthyosaurs of England. Bulletin of the British Museum (Natural History), Geology, 24, 1-109.
McGowan, C. 1974. A revision of the latipinnate ichthyosaurs of the Lower Jurassic of England (Reptilia: Ichthyosauria). Life Sciences Contributions, Royal Ontario Museum, 100, 1-30.

McGowan, C. 1994. Temnodontosaurus risor is a juvenile of T. platyodon (Reptilia: Ichthyosauria). Journal of Vertebrate Paleontology, 14, 472-479.

McGowan, C. 1996. Giant ichthyosaurs of the Early Jurassic. Canadian Journal of Earth Sciences, 33, 1011-1021.

McGowan, C. 2003. A new specimen of Excalibosaurus from the English Lower Jurassic. Journal of Vertebrate Paleontology, 23, 950-956.

McGowan, C. \& Milner, A.C. 1999. A new Pliensbachian ichthyosaur from Dorset, England. Palaeontology, 42, 761-768.

McGowan, C. \& Motani, R. 2003. Handbook of Paleoherpetology, Part 8 Ichthyopterygia. Verlag Dr Friedrich Pfeil, München.

Mellere, D. \& Steel, R.J. 1996. Tidal sedimentation in Inner Hebrides half grabens, Scotland: The Mid-Jurassic Bearreraig Sandstone Formation. In: De Batist, M. \& Jacobs, P. (eds) Geology of Siliciclastic Shelf Seas. Geological Society, London, Special Publications, 117, 49-79.

Miller, H. 1858. The Cruise of the Betsey. Morrison and Gibb, Edinburgh.

Morton, N. 1965. The Bearreraig Sandstone Series (Middle Jurassic) of Skye and Raasay. Scottish Journal of Geology, 1, 189-216.

Morton, N. 1971. Some Bajocian ammonites from western Scotland Palaeontology, 14, 266-293.

Morton, N. 1972. The Bajocian ammonite Dorsetensia in Skye, Scotland. Palaeontology, 14, 266-293.

Morton, N. 1987. Jurassic subsidence history in the Hebrides, NW Scotland. Marine and Petroleum Geology, 4, 226-242.

Morton, N. \& Hudson, J.D. 1995. Field guide to the Jurassic of the Isles of Raasay and Skye, Hebrides and Scotland, Inner Hebrides, NW Scotland. Field Geology of the British Jurassic, Geological Society of London, 209280.

Motani, R. 1999. On the evolution and homologies of ichthyopterygian forefins. Journal of Vertebrate Paleontology, 19, 28-41.

Oates, M.J. 1976. The Lower Lias of Western Scotland. PhD thesis, University of London.

O'Keefe, R.F. 2009. A plesiosaur containing an ichthyosaur embryo as stomach contents from the Sundance formation of the Bighorn Basin, Wyoming. Journal of Vertebrate Paleontology, 29, 1306-1310.

Page, K.N. \& Wimbledon, W.A. 2008. The conservation of Jurassic heritage in the UK-A critical review of the role of governmental organisations and their effectiveness. Volumina Jurassica, 6, 162-173.

Riding, J.B., Walton, W. \& Shaw, D. 1991. Toarcian to Bathonian (Jurassic) palynology of the Inner Hebrides, northwest Scotland. Palynology, 15, 115-179.

Sander, P. M. 2000. Ichthyosauria: their diversity, distribution and phylogeny. Palaeontologische Zeitschrift, 74, 1-35.

Simms, M.J., Chidlaw, N., Morton, N. \& Page, K.N. 2004. British Lower Jurassic Stratigraphy. Geological Conservation Review Series, No. 30, Joint Nature Conservation Committee, Peterborough.

Sollas, W.J. 1916. The skull of Ichthyosaurus studied in serial sections. Philosophical Transactions of the Royal Society of London, Series B, 208, 62-126.

Thrasher, J. 1992. Thermal effect of the Tertiary Cuillins Intrusive Complex in the Jurassic of the Hebrides: An organic geochemical study. In: Parnell, J. (ed.) Basins on the Atlantic Seaboard: Petroleum Geology, Sedimentology and Basin Evolution. Geological Society, London, Special Publications, 62, 35-49, http://dx.doi.org/10.1144/GSL.SP.1992.062.01.06

Torrens, H.S. 1980. Bathonian correlation chart. In: Cope, J.C.W. (ed.) A Correlation of Jurassic Rocks in the British Isles: Part Two: Middle and Upper Jurassic. Blackwell Scientific Publications, London.

Vincent, P., Martin, J.E., et al. 2013. A marine vertebrate fauna from the Toarcian-Aalenian succession of southern Beaujolais, Rhône, France. Geological Magazine, 150, 822-834.

Vincent, P., Taquet, P., Fischer, V., Bardet, N., Falconnet, J. \& Godefroit, P. 2014. Mary Anning's legacy to French vertebrate palaeontology. Geological Magazine, 151, 7-20.

Waldman, M. \& Evans, S.E. 1994. Lepidosauromorph reptiles from the Middle Jurassic of Skye. Zoological Journal of the Linnean Society, 112, 135-150.

Waldman, M. \& Savage, R.J.G. 1972. The first Jurassic mammal from Scotland. Journal of the Geological Society, London, 128, 119-125.

Wilkinson, M. 1991. The concretions of the Bearreraig Sandstone Formation: Geometry and geochemistry. Sedimentology, 38, 899-912.

Wilkinson, M. 1993. Concretions of the Valtos Sandstone Formation of Skye: Geochemical indicators of paleo-hydrology. Journal of the Geological Society, London, 150, 57-66.

Wright, J.K. \& Cox, B.M. 2001. British Upper Jurassic Stratigraphy. Geological Conservation Review Series, No. 21, Joint Nature Conservation Committee, Peterborough. 